\title{
Mesenteric lymph nodes
}
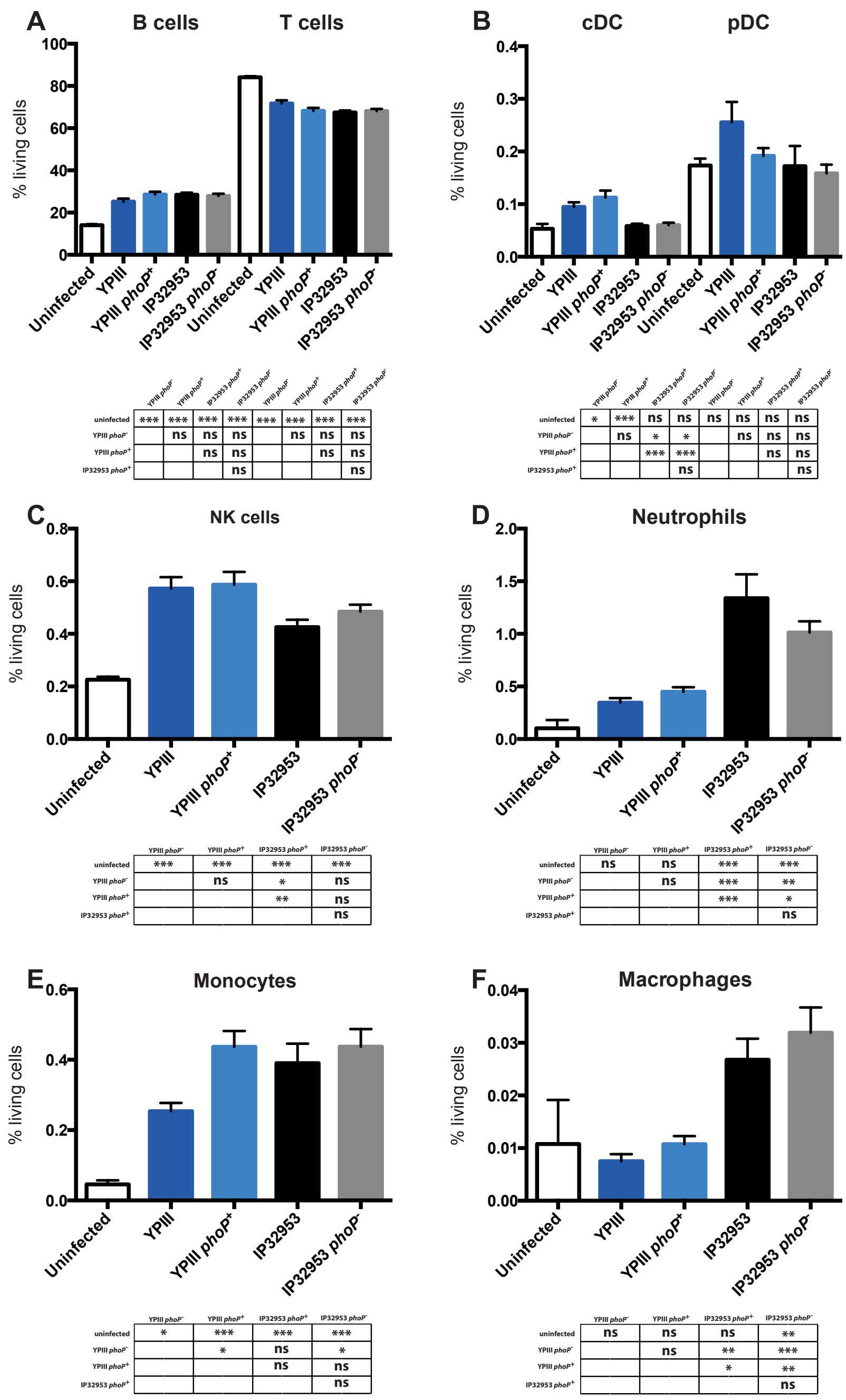

Fig. S4 Pisano et al. 2014 